\title{
KARAKTERISTIK BISKUIT DENGAN PEMANFAATAN UMBI DAN PASTA DAUN SINGKONG (Manihot esculenta Cranz )
}

\author{
Characteristic of Biscuit with The Use of Tuber and Cassava Leaves Paste (Manihot \\ esculenta Cranz)
}

\author{
Ni Kadek Diah Ayu Paramitha ${ }^{1}$, Putu Timur Ina ${ }^{2}$, I Desak Putu Kartika Pratiwi ${ }^{3}$ \\ ${ }^{1}$ Mahasiswa Jurusan Imu dan Teknologi Pangan, Fakultas Teknologi Pertanian, Unud \\ ${ }^{2}$ Dosen Jurusan Imu dan Teknologi Pangan, Fakultas Teknologi Pertanian, Unud \\ PS Ilmu dan Teknologi Pangan, Fakultas Teknologi Pertanian, Universitas Udayana, \\ Kampus Bukit Jimbaran, Badung-Bali
}

\begin{abstract}
The purposes of this research were to know the effect comparation of cassava flour and cassava leaves paste on the characteristics of biscuit and to know the right comparation from cassava flour and cassava leaves paste to produce biscuit the best characteristics. The experimental design was used randomized block design with the treatment comparation of cassava flour and cassava leaves paste that $95 \%: 5 \%, 92 \%: 8 \%, 89 \%: 11 \%$, 86\%: 14\%, 83\%: 17\%; and 80\%: 20\%. The treatment was repeated as many as 3 times so that 18 experimental units were obtained. The data was analyzed with ANOVA and if the influential on variable observed continued with the Duncan test. The results showed that the comparation of cassava flour and cassava leaves paste significantly affected to water content, ash content, crude fiber content, chlorofil total, beta karoten total, and hedonic test (colour, aroma, texture, taste, and overall acceptance) and scoring test (texture). Comparation from cassava flour and cassava leaves paste (92\%: $8 \%$ ) is the best characteristics with water content is $2,77 \%$, ash content was 2,58\%, crude fiber content is $15,39 \%$, chlorofil total is $22,93 \%$, beta karoten total is $434,96 \%$, color liked, flavor of cassava leaves liked, texture very crispy and liked, taste liked, and overall acceptance liked.
\end{abstract}

Keyword : Cassava flour, cassava leaves paste, biscuit, chlorofil, beta karoten

\section{PENDAHULUAN}

Biskuit merupakan salah satu penganan seluruh kalangan masyarakat yang memiliki bentuk pipih, bila dipatahkan penampang potongannya bertekstur padat dengan kadar air maksimal 5\% (Yunisa, 2013). Salah satu bahan utama pembuatan biskuit adalah terigu, dimana dewasa ini penggunaan terigu pada produk pangan di Indonesia semakin lama semakin meningkat. Indonesia belum mampu memproduksi gandum karena dapat tumbuh subur di kawasan subtropis.

Singkong memiliki banyak kegunaan dari umbi, batang dan daunnya. Singkong dapat diolah menjadi tepung singkong untuk memperpanjang umur simpannya. Tepung singkong mengandung karbohidrat, protein, lemak, fosfor, zat besi, kalsium, serta beta karoten (Widowati dan Damardjati, 2001). Tepung singkong banyak digunakan sebagai bahan baku kue, roti tawar, roti manis, mie dan biskuit. Kelemahan biskuit yang beredar di pasaran adalah kandungan vitaminnya yang kurang, maka dewasa ini semakin berkembang banyaknya biskuit yang ditambahkan sayur sayuran untuk meningkatkan nilai gizi. Beberapa penelitian yang dilakukan seperti pada Rudianto et.al.(2014) pembuatan biskuit dengan menggunakan daun kelor (Moringa

*Korespondensi Penulis:

Email: myunartha@gmail.com ${ }^{1}$ 
Oleifera) dan pada penelitian Mayangsari (2018) pembuatan biskuit dengan menggunakan bayam. Selain kedua bahan tersebut, sayuran yang dapat digunakan adalah daun singkong.

Daun singkong murah dan mudah didapat oleh masyarakat Indonesia dengan bentuk yang menjari berwarna hijau muda sampai hijau tua dengan kandungan nutrisi seperti vitamin $\mathrm{A}$, vitamin $\mathrm{B} 1$ dan $\mathrm{C}$, kalsium, fosfor, protein, lemak, dan zat besi (Agoes, 2010). Daun singkong segar mengandung 11.000 SI pro vitamin A. Defisiensi vitamin A dapat menyebabkan seperti kulit kering, keratinisasi, rabun senja,menurunannya fungsi kekebalan tubuh, meningkatnya risiko keguguran dan pertumbuhan yang terganggu (Almatsier, 2011).

Nilai jual umbi singkong dan daun singkong dapat ditingkatkan dengan cara diolah menjadi makanan yang digemari oleh berbagai kalangan seperti biskuit. Penggunaan tepung singkong pada biskuit diharapkan mampu menekan impor terigu yang dilakukan Indonesia serta melakukan diversifikasi pangan lokal. Tujuan penelitian ini adalah perbandingan tepung singkong dan daun singkong terhadap karakteristik biskuit.

\section{METODE PENELITIAN}

\section{Tempat dan Waktu Penelitian}

Penelitian ini dilaksanakan di Laboratorium Pengolahan Pangan, Laboratorium Analisis Pangan dan Laboratorium Rekayasa Proses dan Pengendalian Mutu Fakultas Teknologi Pertanian, Universitas Udayana. Waktu pelaksanaan Februari - April 2018.

\section{Bahan dan Alat}

Bahan untuk melaksanakan penelitian ini terdiri dari bahan baku yakni daun singkong dengan kriteria 3 tangkai dari pucuk batang dan umbi singkong kuning yang didapat dari pasar Bhuana Raya, Kota Denpasar-Bali. Bahan tambahan terdiri dari gula halus (innova), telur, baking powder ( $R \& W)$, skim (vatpro) dan margarin (blue band) yang diperoleh di toko CV. Sinar Pangan. Bahan kimia yang digunakan adalah asam sulfat, natrium hidroksida, alkohol, akuades, aseton, petroleum benzena dan $\mathrm{Na}_{2} \mathrm{SO}_{4}$.

Alat untuk melaksanakan penelitian ini antara lain pisau, sawutan, baskom, oven (cosmos), loyang, panci, kain kasa, blender (miyako), ayakan 60 mesh, oven (wiseTherm), oven (Blue M), cetakan, kuas, loyang, meja, rolling pin, lumpang, cawan, cawan porselin, timbangan analitik (shimadzu), pinset, eksikator, muffle (nabertherm), kompor listrik, spektrofotometer (Genesys 10S UV-Vis), erlenmeyer, gelas beker, gelas ukur, labu ukur, batang pengaduk, tabung reaksi (pyrex), tabung pemisah, waterbath, kertas saring, kertas Whatman 42, corong, gelas plastik, pipet tetes, pipet ukur, pipet mikro, termometer, bola hisap (bulb).

\section{Rancangan Percobaan}

Rancangan penelitian menggunakan Rancangan Acak Kelompok (RAK) dengan perlakuan perbandingan tepung singkong dan pasta daun singkong yang terdiri dari 6 taraf, yaitu : P1 (95\%: $5 \%)$, P2 (92\%: $8 \%)$, P3 (89\%: $11 \%)$, P4 (86\%: $14 \%)$, P5 (83\% : 17 $\%)$, P6 (80 \% : $20 \%)$. Masing - masing perlakuan diulang sebanyak 3 kali sehingga diperoleh 18 unit percobaan. Data yang diperoleh dari hasil penelitian dianalisis dengan ANOVA dan jika perlakuan berpengaruh maka dilanjutkan dengan uji Duncan's (Gomez dan Gomez. 1995). Perlakuan terbaik diperoleh dari uji kimia dan sifat sensoris biskuit.

\section{Pelaksanaan Penelitian}

Proses pembuatan tepung singkong terdiri dari beberapa tahapan yang dikutip dari Koswara. (2009) yang dimodifikasi.Tahap awal umbi singkong kuning disortasi, dikupas dan dicuci. Selanjutnya dikecilkan ukuran dan dikeringkan dengan menggunakan oven 
bersuhu $80^{\circ} \mathrm{C}$ selama 20 jam. Setelah kering dihaluskan dan diayak menggunakan ayakan 60 mesh.

Daun singkong dipisahkan dari ranting, dikecilkan ukurannya, kemudian dicuci dan diblansir dengan cara dikukus pada suhu $80^{\circ} \mathrm{C}$ selama 5 menit. Kemudian ditambahkan air (1:2) antara daun singkong dan air dihancurkan dengan menggunakan blender serta diperas.

Tahapan ketiga adalah proses pembuatan biskuit yang dikutip dari Seprina, (2010) yang modifikasi. Pertama-tama kuning telur, gula bubuk, susu skim dan margarin dicampur. Ditambah tepung singkong dan pasta daun singkong serta baking powder dan air, selanjutnya adonan biskuit tersebut digiling dan dicetak $(4 \times 1,5 \times 0,5 \mathrm{~cm})$, dipanggang di dalam oven selama 30 menit pada suhu $170^{\circ} \mathrm{C}$ sehingga terjadi perubahan warna menjadi coklat keemasan.

Tabel 1. Formula biskuit perbandingan tepung singkong dan pasta daun singkong

\begin{tabular}{lcccccc}
\hline \multicolumn{1}{c}{ Komposisi Bahan } & P1 & P2 & P3 & P4 & P5 & P6 \\
\cline { 2 - 6 } & 95 & 92 & 89 & 86 & 83 & 80 \\
Tepung Singkong & 5 & 8 & 11 & 14 & 17 & 20 \\
Pasta Daun Singkong & 16 & 16 & 16 & 16 & 16 & 16 \\
Gula bubuk Halus & 20 & 20 & 20 & 20 & 20 & 20 \\
Kuning Telur & 25 & 25 & 25 & 25 & 25 & 25 \\
Margarin & 15 & 15 & 15 & 15 & 15 & 15 \\
Susu Skim & 2 & 2 & 2 & 2 & 2 & 2 \\
Baking powder & 20 & 20 & 20 & 20 & 20 & 20 \\
Air & 20
\end{tabular}

Keterangan : \% berdasarkan jumlah tepung singkong dan daun singkong (100 gram)

Sumber : Oluwamukomi, et al., (2011) yang dimodifikasi

\section{Variabel yang Diamati}

Variabel yang diamati meliputi analisis kadar air dengan metode pengeringan (Sudarmadji et al., 1997), kadar abu dengan metode pengeringan (Sudarmadji et al., 1997), kadar serat kasar dengan metode hidrolisis asam basa (Sudarmadji et al,1997), total klorofil (Nollet, 2004) total beta karoten (Muchtadi, 1989), dan uji sensori (Soekarto, 1985)

\section{HASIL DAN PEMBAHASAN}

Hasil analisis kadar air, kadar abu, kadar serat kasar, total klorofil, dan total beta karoten dari tepung singkong dan pasta daun singkong yang digunakan pada Tabel 2.

\section{Kadar Air}

Hasil ANOVA menunjukkan bahwa kadar air biskuit pada perbandingan tepung singkong dan pasta daun singkong berpengaruh nyata
$(\mathrm{P}<0,05)$. Kadar air biskuit tertinggi (Tabel 3) diperoleh dari biskuit pada perlakuan P6 (80\% tepung singkong dan $20 \%$ pasta daun singkong) yaitu 3,38\%, sedangkan kadar air biskuit terendah diperoleh dari biskuit dengan perlakuan P1 (95\% tepung singkong dan 5\% pasta daun singkong) yaitu $2,64 \%$. Pembuatan biskuit dengan penambahan pasta daun singkong yang semakin meningkat menghasilkan biskuit dengan kadar air yang semakin meningkat. Hal tersebut karena kadar air pasta daun singkong yang lebih tinggi dari tepung singkong. Pada analisis bahan baku (Tabel 2) kadar air pasta daun singkong adalah $69,43 \%$, sedangkan tepung singkong $7,68 \%$. Besarnya nilai kadar air menurut standar mutu biskuit maksimal 5\% (Anon.,2011), jadi kadar air biskuit yang dihasilkan telah memenuhi standar mutu biskuit.

\section{Kadar Abu}

Hasil ANOVA menunjukkan bahwa kadar 
Tabel 2. Nilai rerata kadar air, kadar abu, kadar serat kasar, total klorofil, dan total beta karoten dari tepung singkong dan pasta daun singkong.

\begin{tabular}{lcc}
\hline \multicolumn{1}{c}{ Komponen } & Tepung Singkong & Pasta Daun Singkong \\
\hline Kadar air $(\% \mathrm{~b} / \mathrm{b})$ & $7,68 \pm 0,02$ & $69,43 \pm 0,07$ \\
Kadar Abu $(\% \mathrm{~b} / \mathrm{b})$ & $13,57 \pm 0,27$ & $20,43 \pm 0,62$ \\
Serat Kasar $(\% \mathrm{~b} / \mathrm{b})$ & $13,78 \pm 0,21$ & $24,14 \pm 0,06$ \\
Total Klorofil $(\mathrm{mg} / \mathrm{kg})$ & $0,90 \pm 0,01$ & $144,57 \pm 2,37$ \\
Total Beta karoten $(\mu \mathrm{g} / 100 \mathrm{~g})$ & $34,10 \pm 2,42$ & $3.167,70 \pm 4$ \\
\hline
\end{tabular}

Hasil analisis kadar air, kadar abu dan kadar serat kasar dari biskuit pada Tabel 3.

Tabel 3. Nilai reratakadar air, kadar abu, kadar serat kasar, dari biskuit

\begin{tabular}{cccccc}
\hline Perlakuan & $\begin{array}{c}\text { Kadar air } \\
(\% \mathrm{~b} / \mathrm{b})\end{array}$ & $\begin{array}{c}\text { Kadar abu } \\
(\% \mathrm{~b} / \mathrm{b})\end{array}$ & $\begin{array}{c}\text { Serat Kasar } \\
(\% \mathrm{~b} / \mathrm{b})\end{array}$ & $\begin{array}{c}\text { Total klorofil } \\
(\mathrm{mg} / \mathrm{kg})\end{array}$ & $\begin{array}{c}\text { Total beta karoten } \\
(\mu \mathrm{g} / 100 \mathrm{~g})\end{array}$ \\
\hline P1 & $2,64 \pm 0,05 \mathrm{f}$ & $2,30 \pm 0,17 \mathrm{e}$ & $14,97 \pm 0,05 \mathrm{f}$ & $15,26 \pm 3,36 \mathrm{~d}$ & $249,72 \pm 9,18 \mathrm{f}$ \\
P2 & $2,77 \pm 0,04 \mathrm{e}$ & $2,58 \pm 0,04 \mathrm{~d}$ & $15,39 \pm 0,13 \mathrm{e}$ & $22,93 \pm 6,46 \mathrm{c}$ & $434,96 \pm 63,97 \mathrm{e}$ \\
P3 & $2,88 \pm 0,03 \mathrm{~d}$ & $2,75 \pm 0,12 \mathrm{c}$ & $16,84 \pm 0,11 \mathrm{~d}$ & $30,69 \pm 11,73 \mathrm{~b}$ & $571,77 \pm 82,11 \mathrm{~d}$ \\
P4 & $3,04 \pm 0,04 \mathrm{c}$ & $2,95 \pm 0,05 \mathrm{~b}$ & $17,51 \pm 0,32 \mathrm{c}$ & $33,72 \pm 10,90 \mathrm{~b}$ & $715,05 \pm 72,73 \mathrm{c}$ \\
P5 & $3,22 \pm 0,04 \mathrm{~d}$ & $3,06 \pm 0,08 \mathrm{a}$ & $17,85 \pm 0,07 \mathrm{~b}$ & $41,56 \pm 11,19 \mathrm{a}$ & $919,73 \pm 40,62 \mathrm{~b}$ \\
P6 & $3,38 \mathrm{a} \pm 0,08$ & $3,13 \pm 0,02 \mathrm{a}$ & $18,25 \pm 0,19 \mathrm{a}$ & $46,00 \pm 14,09 \mathrm{a}$ & $1.103,44 \pm 106,49 \mathrm{a}$ \\
\hline
\end{tabular}

Keterangan : Nilai rerata yang diikuti oleh huruf yang berbeda pada kolom yang sama menunjukkan berbeda nyata pada Uji Duncan $(\alpha=0,05)$

abu biskuit pada perbandingan tepung singkong dan pasta daun singkong berpengaruh nyata $(\mathrm{P}<0,05)$. Kadar abu biskuit tertinggi (Tabel 3) diperoleh dari biskuit pada perlakuan P6 (80\% tepung singkong dan 20\% pasta daun singkong) yaitu 3,13\% dan tidak berbeda dengan perlakuan P5, sedangkan kadar abu biskuit terendah diperoleh dari biskuit dengan perlakuan P1 (95\% tepung singkong dan 5\% pasta daun singkong) yaitu 2,30\%. Pembuatan biskuit dengan penambahan pasta daun singkong yang semakin meningkat menghasilkan biskuit dengan kadar abu yang semakin tinggi. Hal tersebut karena kadar abu pasta daun singkong yang lebih tinggi dari tepung singkong. Berdasarkan analisis bahan baku (Tabel 2) kadar abu pasta daun singkong adalah 20,43\%, sedangkan tepung singkong 13,57\%. Menurut Anon. (1992c) bahwa kandungan kalsium pada daun singkong sebesar $165 \mathrm{mg} / \mathrm{kg}$, fosfor sebesar $54 \mathrm{mg} / \mathrm{kg}$ dan zat besi sebesar $2 \mathrm{mg} / \mathrm{kg}$ yang merupakan bagian dari mineral.

\section{Kadar Serat Kasar}

Hasil ANOVA menunjukkan bahwa kadar serat kasar biskuit pada perbandingan tepung singkong dan pasta daun singkong berpengaruh nyata $(\mathrm{P}<0,05)$ terhadap kadar serat kasar biskuit. Kadar serat kasar biskuit tertinggi (Tabel 3) diperoleh dari biskuit pada perlakuan P6 (80\% tepung singkong dan 20\% pasta daun singkong) yaitu $18,25 \%$, sedangkan kadar serat kasar biskuit terendah diperoleh dari biskuit dengan perlakuan P1 (95\% tepung singkong dan 5\% pasta daun singkong) yaitu 14,97\%. Pembuatan biskuit dengan penambahan pasta daun singkong yang semakin meningkat menghasilkan biskuit dengan kadar serat kasar yang semakin tinggi.Dikarenakan kadar serat kasar pasta daun singkong yang lebih tinggi dari tepung singkong. Berdasarkan analisis bahan baku (Tabel 2) kadar serat kasar pasta daun singkong adalah $24,14 \%$, sedangkan tepung singkong $13,78 \%$. Besarnya nilai kadar serat kasar menurut standar mutu biskuit maksimal 0,5\% (Anon.,2011), sehingga kadar serat kasar biskuit tepung singkong dengan penambahan 
pasta daun singkong lebih tinggi dari standar biskuit sehingga semua perlakuan tidak memenuhi Standar Nasional Indonsesia (SNI). Serat kasar adalah tidak dapat dihidrolisis oleh bahan kimia sedangkan serat pangan tidak dapat dihidrolisis dengan enzim pencernaan. Menurut Kusharto (2006) serat pangan mampu menambah volume dan melunakkan konsistensi feses serta menghambat kanker kolon.

\section{Total Klorofil}

Hasil ANOVA menunjukkan bahwa total klorofil biskuit pada perbandingan tepung singkong dan pasta daun singkong berpengaruh nyata $(\mathrm{P}<0,05)$. Total klorofil tertinggi (Tabel 3) diperoleh dari biskuit pada perlakuan P6 (80\% tepung singkong dan 20\% pasta daun singkong) yaitu $46,00 \mathrm{mg} / \mathrm{kg}$ dan tidak berbeda dengan perlakuan P5, sedangkan total klorofil biskuit terendah diperoleh dari biskuit dengan perlakuan P1 (95\% tepung singkong dan 5\% pasta daun singkong) yaitu $15,26 \mathrm{mg} / \mathrm{kg}$. Pembuatan biskuit dengan penambahan pasta daun singkong yang semakin meningkat menghasilkan biskuit dengan total klorofil yang semakin tinggi. Hal ini dikarenakan total klorofil pasta daun singkong yang lebih tinggi dari tepung singkong. Berdasarkan analisis bahan baku (Tabel2) total klorofil pasta daun singkong adalah $144,57 \mathrm{mg} / \mathrm{kg}$ sedangkan tepung singkong $0,90 \mathrm{mg} / \mathrm{kg}$. Menurut Madalena et.al.,(2007) kandungan klorofil daun singkong segar adalah $3050 \mathrm{mg} / \mathrm{kg}$ dan menurun menjadi $2680 \mathrm{mg} / \mathrm{kg}$ setelah dilakukan pemanasan dengan cara direbus selama 10 menit. Menurut Winarno (2004) klorofil adalah suatu pigmen yang ada di dalam kloroplas dengan karoten dan xantofil. Fungsi klorofil untuk kesehatan yakni meningkatkan antibodi, memproduksi sel darah merah, antibakteri dan anti kanker.

\section{Total Beta Karoten}

Hasil ANOVA menunjukkan bahwa total beta karoten biskuit pada perbandingan tepung singkong dan pasta daun singkong berpengaruh nyata $(\mathrm{P}<0,05)$. Total beta karoten biskuit tertinggi (Tabel 3) diperoleh dari biskuit pada perlakuan P6 (80\% tepung singkong dan $20 \%$ pasta daun singkong) yaitu $1.103,44 \mu \mathrm{g} / 100 \mathrm{~g}$, sedangkan total beta karoten biskuit terendah diperoleh dari biskuit dengan perlakuan P1 (95\% tepung singkong dan 5\% pasta daun singkong) yaitu 249,72 $\mu \mathrm{g} / 100 \mathrm{~g}$. Pembuatan biskuit dengan penambahan pasta daun singkong yang semakin meningkat menghasilkan biskuit dengan total beta karoten yang semakin tinggi. Hal ini disebabkan karena total beta karoten pasta daun singkong yang lebih tinggi dari tepung singkong. Berdasarkan analisis bahan baku (Tabel 2) total beta karoten pasta daun singkong adalah $3.167,70 \mu \mathrm{g} / 100 \mathrm{~g}$ sedangkan tepung singkong 34,10 $\mu \mathrm{g} / 100 \mathrm{~g}$. Menurut Madalena et.al.,(2007) kandungan karotenoid daun singkong segar adalah $807 \mu \mathrm{g} / \mathrm{g}$ dan menurun menjadi $664 \mu \mathrm{g} / \mathrm{g}$ setelah dilakukan pemanasan dengan cara direbus selama 10 menit. Menurut Winarno, (1992) bahwa semakin hijau daun maka semakin tinggi kadar karotennya. Fungsi beta karoten bagi kesehatan adalah untuk mencegah rabun senja, kulit kering, keratinisasi dan menurunkan risiko keguguran atau kesukaran dalam melahirkan.

\section{Evaluasi Sifat Sensoris}

Nilai rerata uji hedonik terhadap warna, aroma, tekstur, rasa dan penerimaan keseluruhan biskuit pada Tabel 4. Nila rerata uji skoring terhadap tekstur pada Tabel 5.

\section{Warna}

Hasil ANOVA menunjukkan bahwa warna biskuit pada perbandingan tepung singkong dan pasta daun singkong berpengaruh nyata $(\mathrm{P}<0,05$. Nilai rerata tertinggi (Tabel 4) diperoleh dari biskuit pada perlakuan P1 (95\% tepung singkong dan 5\% pasta daun singkong) yaitu suka dan tidak berbeda dengan perlakuan 
P2, sedangkan rerataterendah diperoleh dari biskuit pada perlakuan P6 (80\% tepung singkong dan $20 \%$ pasta daun singkong) yaitu biasa dan tidak berbeda dengan perlakuan P5.

\section{Tekstur}

Hasil ANOVA menunjukkan bahwa tekstur biskuit pada perbandingan tepung singkong dan pasta daun singkong berpengaruh nyata $(\mathrm{P}<0,05)$. Nilai rerata tertinggi (Tabel 4) diperoleh dari biskuit pada perlakuan P1 (95\% tepung singkong dan 5\% pasta daun singkong) yaitu suka dan tidak berbeda dengan perlakuan P2 sedangkan rerataterendah diperoleh dari biskuit pada perlakuan P6 (80\% tepung singkong dan $20 \%$ pasta daun singkong) yaitu biasa. Nilai rerata penerimaan terhadap skoring tekstur biskuit tertinggi (Tabel 5) pada perlakuan P1 sangat renyah dan tidak berbeda dengan perlakuan $\mathrm{P} 2$, sedangkan rerata terendah diperoleh dari biskuit pada perlakuan P6 (80\% tepung singkong dan 20\% pasta daun singkong) yaitu renyah dan tidak berbeda dengan perlakuan P4 serta P5. Meningkatnya jumlah pasta daun singkong yang ditambahkan ke dalam adonan menghasilkan adonan yang semakin lunak. Hal ini disebabkan kadar air pada biskuit dengan perlakuan P1 (95\% tepung singkong dan 5\% pasta daun singkong) paling kecil dan P6 (80\% tepung singkong dan 20\% pasta daun singkong) memiliki kadar air terbesar.

Tabel 4. Nilai rerata uji hedonik warna, aroma, tekstur, rasa dan penerimaan keseluruhan

\begin{tabular}{cccccc}
\hline Perlakuan & \multicolumn{5}{c}{ Nilai rerata uji hedonik } \\
\cline { 2 - 6 } & Warna & Tekstur & Aroma & Rasa & $\begin{array}{c}\text { Penerimaan } \\
\text { Keseluruhan }\end{array}$ \\
\cline { 2 - 6 } P1 & $5,87 \pm 0,64 \mathrm{a}$ & $5,87 \pm 0,74 \mathrm{a}$ & $5,67 \pm 0,82 \mathrm{a}$ & $5,73 \pm 0,80 \mathrm{a}$ & $5,87 \pm 0,52 \mathrm{a}$ \\
P2 & $5,80 \pm 0,56 \mathrm{a}$ & $5,67 \pm 0,49 \mathrm{a}$ & $5,60 \pm 0,74 \mathrm{ab}$ & $5,67 \pm 0,72 \mathrm{a}$ & $5,60 \pm 0,51 \mathrm{ab}$ \\
P3 & $5,40 \pm 0,63 \mathrm{~b}$ & $5,07 \pm 0,70 \mathrm{~b}$ & $5,53 \pm 0,52 \mathrm{ab}$ & $5,07 \pm 0,59 \mathrm{~b}$ & $5,47 \pm 0,52 \mathrm{ab}$ \\
P4 & $4,47 \pm 0,64 \mathrm{c}$ & $5,00 \pm 0,76 \mathrm{~b}$ & $5,27 \pm 0,46 \mathrm{bc}$ & $4,67 \pm 0,62 \mathrm{bc}$ & $5,33 \pm 0,49 \mathrm{~b}$ \\
P5 & $4,27 \pm 0,59 \mathrm{~cd}$ & $4,87 \pm 0,74 \mathrm{~b}$ & $5,00 \pm 0,38 \mathrm{c}$ & $4,27 \pm 0,88 \mathrm{~cd}$ & $4,67 \pm 0,82 \mathrm{c}$ \\
P6 & $4,00 \pm 0,38 \mathrm{~d}$ & $4,40 \pm 0,63 \mathrm{c}$ & $4,53 \pm 0,52 \mathrm{~d}$ & $3,87 \pm 0,74 \mathrm{~d}$ & $4,20 \pm 0,94 \mathrm{~d}$ \\
\hline
\end{tabular}

Keterangan : Nilai rerata yang diikuti oleh huruf yang berbeda pada kolom yang sama menunjukkan berbeda nyata pada Uji Duncan $(\alpha=0,05)$

Kriteria hedonik : 1 (sangat tidak suka), 2 (tidak suka), 3 (agak tidak suka), 4 (biasa), 5 (agak suka), 6 (suka), 7 (sangat suka)

Tabel 5. Nilai rerata uji skoring tekstur

\begin{tabular}{cc} 
Perbandingan & Tekstur \\
(tepung singkong : pasta daun singkong) & \\
\hline P1 & $3,87 \pm 0,52 \mathrm{a}$ \\
P2 & $3,73 \pm 0,59 \mathrm{a}$ \\
P3 & $3,00 \pm 0,53 \mathrm{~b}$ \\
P4 & $2,93 \pm 0,46 \mathrm{bc}$ \\
P5 & $2,87 \pm 0,35 \mathrm{bc}$ \\
P6 & $2,60 \pm 0,51 \mathrm{c}$ \\
\hline
\end{tabular}

Keterangan : Nilai rerata yang diikuti oleh huruf yang berbeda pada kolom yang sama menunjukkan berbeda nyata pada Uji Duncan $(\alpha=0,05)$

Kriteria skoring : 1 (tidak renyah), 2 (agak renyah), 3 (renyah), 4 (sangat renyah), 5 (amat sangat renyah)

\section{Aroma}

Hasil ANOVA menunjukkan bahwa aroma biskuit pada perbandingan tepung singkong dan pasta daun singkong berpengaruh nyata $(\mathrm{P}<0,05)$. Nilai rerata tertinggi (Tabel 4) diperoleh dari biskuit pada perlakuan P1 (95\% tepung singkong dan 5\% pasta daun singkong) yaitu suka dan tidak berbeda dengan perlakuan P2 serta P3, sedangkan rerataterendah diperoleh dari biskuit pada perlakuan P6 (80\% 
tepung singkong dan $20 \%$ pasta daun singkong) yaitu agak suka.

\section{Rasa}

Hasil ANOVA menunjukkan bahwa rasa biskuit pada perbandingan tepung singkong dan pasta daun singkong berpengaruh nyata $(\mathrm{P}<0,05)$. Nilai rerata tertinggi (Tabel 4) diperoleh dari biskuit pada perlakuan P1 (95\% tepung singkong dan 5\% pasta daun singkong) yaitu suka dan tidak berbeda nyata dengan perlakuan P2, sedangkan rerataterendah diperoleh dari biskuit pada perlakuan P6 (80\% tepung singkong dan $20 \%$ pasta daun singkong) yaitu biasa serta tidak berbeda dengan perlakuan P5. Semakin tinggi penambahan pasta daun singkong akan menyebabkan rasa biskuit menjadi tidak disukai oleh panelis.

\section{Penerimaan keseluruhan}

Hasil ANOVA menunjukkan bahwa penerimaan keseluruhan biskuit pada perbandingan tepung singkong dan pasta daun singkong berpengaru nyata $(\mathrm{P}<0,05)$. Nilai rerata tertinggi (Tabel 4) diperoleh dari biskuit pada perlakuan P1 (95\% tepung singkong dan $5 \%$ pasta daun singkong) yaitu suka serta tidak berbeda dengan P2 dan P3, sedangkan rerataterendah diperoleh dari biskuit pada perlakuan P6 (80\% tepung singkong dan 20\% pasta daun singkong) yaitu biasa. Penerimaan biskuit dipengaruhi oleh beberapa faktor, yakni warna, aroma, tekstur dan rasa.

\section{SIMPULAN DAN SARAN}

\section{Simpulan}

1. Perbandingan tepung singkong dengan pasta daun singkong berpengaruh terhadap kadar air, kadar abu, kadar serat kasar, total klorofil, total beta karoten, warna (uji hedonik), tekstur (uji hedonik), aroma (uji hedonik), rasa (uji hedonik), penerimaan keseluruhan (uji hedonik) serta berpengaruh terhadap tekstur (uji skoring) biskuit.
2. Perlakuan terbaik adalah P2 dengan perbandingan $92 \%$ tepung singkong : $8 \%$ pasta daun singkong menghasilkan biskuit dengan karakteristik terbaik yaitu kadar air 2,77\%, kadar abu 2,58\%, kadar serat kasar $15,39 \%$, total klorofil $22,93 \mathrm{mg} / \mathrm{kg}$, total beta karoten 434,96 $\mu \mathrm{g} / 100 \mathrm{~g}$, warna disukai, tekstur sangat renyah dan disukai , aroma disukai, penerimaan keseluruhan disukai.

\section{Saran}

Berdasarkan hasil penelitian, umtuk menghasilkan biskuit terbaik disarankan menggunakan perbandingan $92 \%$ tepung singkong : $8 \%$ pasta daun singkong.

\section{DAFTAR PUSTAKA}

Agoes, A. 2010. Tanaman Obat Indonesia. Salemba Medica, Palembang.

Anonimus. 1992. Badan Standar Nasional Indonesia. Daftar Komposisi Bahan Makanan. BSN. Jakarta.

Anonimus. 2011. Badan Standar Nasional Indonesia. Mutu dan Cara Uji Biskuit (SNI 01-2973-2011). BSN. Jakarta.

Almatsier, S. 2011. Prinsip Dasar Ilmu Gizi. PT Gramedia Pustaka Utama, Jakarta.

Gomes, K. A. dan A. A. Gomes. 1995. Prosedur Statistik Untuk Penelitian Pertanian. UI Press. Jakarta.

Koswara. 2009. Teknologi Modifikasi Pati. eBook Pangan.com. diakses pada tanggal: 2 Desember 2017

Kusharto, C.M. 2006. Serat makanan dan peranannya bagi kesehatan. Jurnal Gizi dan Pangan. Vol. 1(2) : 45-54

Madalena, Hariyanto, S.P.Hastuti dan L.Limantara. 2007. Pengaruh lama 
pemanasan terhadap kandungan pigmen serta vitamin a daun singkong (manihot esculenta crantz) dan daun singkong karet (manihot glaziovii muell. Arg). Indo.J.Chem. Vol 7(1) : 105-110

Muchtadi, D. 1989. Evaluasi Nilai Gizi Pangan. Departemen Pendidikan dan Kebudayaan Direktorat Jenderal Pendidikan Pusat Tinggi Antar Universitas Pangan dan Gizi. Institut Pertanian Bogor.

Nollet, L.M.L. 2004. Handbook of Food Analysis. Physical Characterzati-ion and Nutrient Analysis. Marcel Dekker. Inc. 1(2). New York.

Oluwamukomi. M.O, I.B. Oluwalana dan O.F. Akinbowale.2011. Physicochemical and sensory properties of wheat-cassava composite biskuit eriched with soy flour. African Journal of Food Science. Vol 5(2) : 50-56.

Rudianto, A. Syam, S.Alharini. 2014. Studi pembuatan dan analisis zat gizi pada produk biskuit moringan oliefera dengan substitusi tepung daun kelor. Jurnal Kesehatan Masyarakat. Vol 1(1) : 1-13

Seprina, A. 2010. Kajian Substitusi Tepung Terigu dan Residu Ekstrak Pati Jagung (Zea mays L.) dalam Pembuatan Biskuit Berserat. Skripsi. Tidak dipublikasi. Universitas Lampung, Bandar Lampung.

Soekarno, S.T. 1985. Penilaian Organoleptik Untuk Industri Pangan dan Pertanian. Bharata Karya Aksara. Jakarta.

Sudarmadji, S., B. Haryono dan Suhardi. 1997. Prosedur Analisa Untuk Bahan Makanan dan Pertanian. Liberty, Yogyakarta.

Widowati, S. dan D. S. Damardjati. 2001. Menggali Sumber daya Pangan Lokal dan Peran Teknologi Pangan Dalam Rangka
Ketahanan Pangan Nasional. Majalah Pangan. 6:3-11.

Winarno. F.G. 1992. Kimia Pangan dan Gizi. PT. Gramedia Pustaka Utama. Jakarta.

Winarno F.G. 2004. Kimia Pangan dan Gizi. PT. Gramedia Pustaka Utama. Jakarta.

Yunisa. 2013. Kajian Konsentrasi Koji Bacillus substilis dan Waktu Fermentasi Terhadap Karakteristik Tepung Ubi Jalar yang Dimodifikasi dan Aplikasinya dalam Pembuatan Biskuit. Skripsi. Tidak dipublikasi. Jurusan Teknologi Pangan Fakultas Teknik Universitas Pasundan, Bandung. 